\title{
Sedimentary Iron Cycling and the Origin and Preservation of Magnetization in Platform Carbonate Muds, Andros Island, Bahamas
}

\author{
Adam C. Maloof ${ }^{\text {a,* }}$, Robert E. Kopp ${ }^{\mathrm{b}}$, John P. Grotzinger ${ }^{\mathrm{b}}$, \\ David A. Fike ${ }^{\mathrm{c}}$, Tanja Bosak ${ }^{\mathrm{c}}$, Hojotollah Vali ${ }^{\mathrm{d}}$, \\ Pascale M. Poussart ${ }^{\mathrm{a}}$, Benjamin P. Weiss ${ }^{\mathrm{c}}$ and \\ Joseph L. Kirschvink ${ }^{b}$ \\ ${ }^{a}$ Department of Geosciences, Princeton University, \\ Guyot Hall, Washington Road, Princeton, NJ 08544, USA \\ ${ }^{\mathrm{b}}$ Division of Geological \& Planetary Sciences, California Institute of Technology, \\ 1200 E. California Blvd., Pasadena, CA 91125, USA \\ ${ }^{\mathrm{c}}$ Department of Earth, Atmospheric \& Planetary Sciences, Massachusetts Institute of \\ Technology, \\ 77 Massachusetts Avenue, Cambridge, MA, 02139 USA \\ ${ }^{\mathrm{d}}$ Faculty of Dentistry, McGill University, \\ 3640 University Street, Montreal, Quebec H3A 2B2, Canada
}

Received 25 January 2007; received in revised form 10 May 2007; accepted 11 May 2007.

Editor: M. L. Delaney. Copyright (c 2007 Published by Elsevier B.V.

Available online 23 May 2007. doi:10.1016/j.epsl.2007.05.021

\begin{abstract}
Carbonate muds deposited on continental shelves are abundant and well-preserved throughout the geologic record because shelf strata are difficult to subduct and peritidal carbonate units often form thick, rheologically strong units that resist penetrative deformation. Much of what we know about pre-Mesozoic ocean chemistry, carbon cycling, and global change is derived from isotope and trace element geochemistry of platform carbonates. Paleomagnetic data from the same sediments would be invaluable, placing records of paleolatitude, paleogeography, and perturbations to the geomagnetic field in the context and relative chronology of chemostratigraphy. To investigate the depositional and early diagenetic processes that contribute to magneitzation in carbonates, we surveyed over 500 core and surface samples of peritidal, often microbially bound carbonate muds spanning the last 1000 years and deposited on top of Pleistocene aeolianites in the Triple Goose Creek region of northwest Andros Island, Bahamas. Sedimentological, geochemical, magnetic and ferromagnetic resonance properties divide the sediment columns into three biogeochemi-
\end{abstract}


cal zones. In the upper sediments, the dominant magnetic mineral is magnetite, produced by magnetotactic bacteria and dissimiliatory microbial iron metabolism. At lower depths, above or near mean tide level, microbial iron reduction dissolves most of the magnetic particles in the sediment. In some cores, magnetic iron sulfides precipitate in a bottom zone of sulfate reduction, likely coupled to the oxidation of decaying mangrove roots. The remanent magnetization preserved in all oriented samples appears indistinguishable from the modern local geomagnetic field, which reflects the post-depositional origin of magnetic particles in the lower zone of the parasequence. While we cannot comment on the effects of late-stage diagenesis or metamorphism on remanence in carbonates, we postulate that early-cemented, thin-laminated parasequence tops in ancient peritidal carbonates are mostly likely to preserve syn-depositional paleomagnetic directions and magnetofossil stratigraphies.

Key words: sedimentary magnetism; paleomagnetism; carbonate platform; parasequence; Bahamas

\section{Introduction}

Like all sediments, platform carbonates provide, in their stratigraphy and sedimentology, a local record of changing environmental conditions. However, as chemical sediments, carbonates also carry a record of regional and global ocean chemistry and biogeochemical cycling. Coupling the environmental and geochemical record available in carbonates to paleomagnetic data places proxy data in a richer global context by providing paleolatitude information and enabling paleogeographic reconstructions and magnetostratigraphic correlations. In the Neoproterozoic $(\sim 800$ Ma) Akademikerbreen Group of Svalbard, Norway, for instance, stratigraphic, geochemical and paleomagnetic data from platform carbonate sediments provide the best evidence to date for rapid true polar wander (Maloof et al., 2006). Coupled measurements also provide a way of studying the influence of climate on sedimentary magnetism (Evans and Heller, 2003), as well as testing hypotheses about the influence of geomagnetic intensity on climate (Courtillot et al., 2007).

Where clastic input is low, carbonate platform sediments are often magnetically weak and extraction of their primary paleomagnetic signals requires special care (Maloof et al., 2006; McNeill, 1997; Montgomery et al., 1998). In the absence of significant clastic flux, iron cycling in the stratigraphic column should leave a strong imprint on sediment magnetic properties. Processes expected to be important in the iron cycle include the production of magnetite and iron sulfides as byproducts of bacterial metabolism, the reductive dissolution of magnetic particles by iron-reducing bacteria, and the intracellular precipitation of magnetite and greigite by magnetotactic bacteria (Bazylinski et al., 1994; Sakaguchi et al., 2002; Simmons et al., 2004). Fossil magnetotactic bacteria, called magnetofossils, have previously been identified as a major magnetic constituent in sediments in Holocene (e.g., Kirschvink and Chang, 1984; McNeill, 1990), Neogene (e.g., McNeill et al.,

\footnotetext{
* Corresponding author. Tel.: (609) 258-2844; Fax: (609) 258-1274; E-mail: maloof@ princeton.edu
} 
1988; Sakai and Jige, 2006), Cretaceous (Montgomery et al., 1998), and perhaps older (Belkaaloul and Aissaoui, 1997; Chang et al., 1989; Chang and Kirschvink, 1989) shallow marine carbonates.

Prior studies of primary magnetic remanence preservation in platform carbonates have focused on (1) the consequences of dolomitization in subtidally-deposited Neogene rocks from cores through the Bahamas platform (McNeill, 1997; McNeill et al., 1988; McNeill and Kirschvink, 1993) and (2) secondary magnetite growth in orogenic pore fluids in Lower Paleozoic carbonates of the midcontinental United States (McCabe et al., 1983; McCabe and Elmore, 1989; McCabe et al., 1989; Van der Voo, 1989; Jackson, 1990; Jackson et al., 1992). The interpretation of magnetic records in ancient carbonates would be strengthened by a detailed understanding of the sedimentary iron cycle and its role in altering magnetic mineralogies during early diagenesis. Furthermore, understanding the relationship between sedimentological sequences and magnetism could provide a magnetic signature useful for the interpretation of cyclostratigraphy. In this paper we present sedimentological, geochemical, magnetic, and ferromagnetic resonance analyses of carbonates from a Recent shoaling-upward subtidal-to-supertidal parasequence in the Triple Goose Creek region of northwestern Andros Island (Bahamas) and evaluate the origin and preservation of primary magnetic remanence.

\section{Geological Setting}

The Bahamas archipelago is a carbonate depositional environment consisting of several isolated platforms at the southern extremity of North America's eastern continental margin. Andros is the largest island in the Bahamas, located on the raised eastern rim of the western half of the Great Bahama Bank, and bounded by seaways to the east (Tongue of the Ocean) and west (Straits of Florida). The positive relief of Andros Island is composed of Pleistocene carbonate dunes overlying karsted and cemented coral reef (Fig. 1).

Andros Island has a tropical-maritime climate, with wet summers, dry winters, and fairly uniform monthly average temperatures of $\sim 25^{\circ} \mathrm{C}$ (Hardie, 1977). Annual average rainfall is $\sim 130$ $\mathrm{cm} / \mathrm{yr}$ (Hardie, 1977), making Andros significantly wetter than other Holocene carbonate platforms such as Abu Dhabi (annual average rainfall $\sim 12 \mathrm{~cm} / \mathrm{yr}$ ). Prevailing northeasterly trade winds are strongest and most variable in the winter, and often dominate the semi-diurnal lunar-solar tide.

Triple Goose Creek (TGC) is located on the northwestern edge of Andros Island (Fig. 1). TGC has long captured the imaginations of carbonate sedimentologists because it is a rare Holocene example of a wet carbonate platform with a well-developed intertidal zone characterized by meandering channels (Fig. 2). Virtually all carbonate sediment delivered to the intertidal and supratidal zones of TGC is derived from aragonite-producing green algae such as Halimeda, Penicillus and Udotea. Without a riverine flux of siliciclastic sediment, the only significant iron in the TGC system is derived from plumes of dust originating in Saharan West Africa (Moore et al., 2002).

Shinn et al. (1969) and Hardie et al. (1977) first documented the major physiographic elements of TGC. On the landward eastern side, a flat, mostly supertidal 3-8 km wide inland algal marsh 


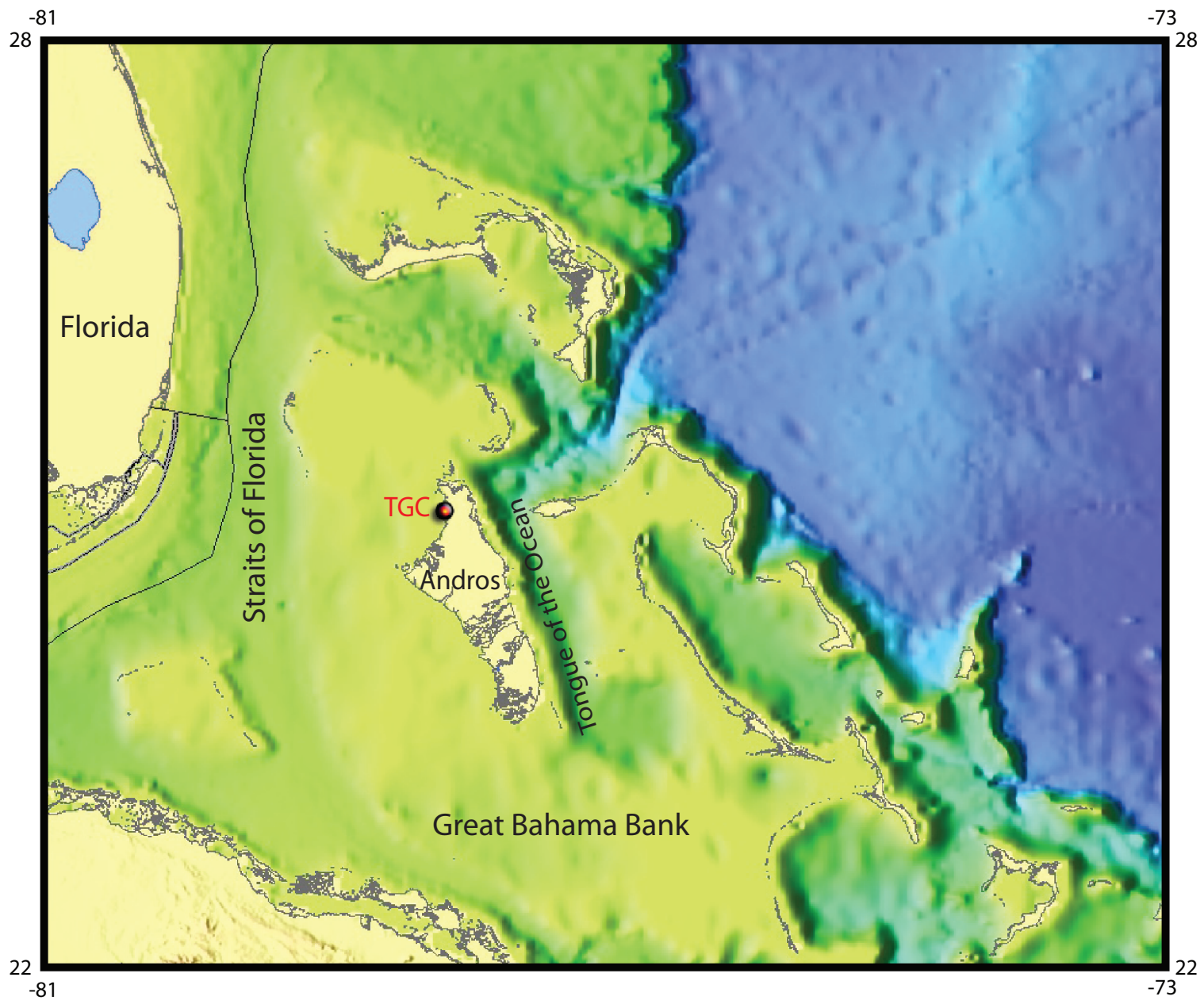

Figure 1. Bathymetry of the Great Bahama Bank from NOAA's ETOPO2 (USGS CMG InfoBank Atlas). TGC-Triple Goose Creek (Fig. 2)

(IAM) is characterized by luxuriant Scytonema filamentous cyanobacterial mat communities and dessicated carbonate mud flats left by hurricane surges. The stratigraphic thickness of Holocene mud increases seaward, from emergent cemented Pleistocene dune sands in the east to $1 \mathrm{~m}$ of Holocene mud along the western fringe of the IAM.

A central intertidal zone, 1-4 $\mathrm{km}$ wide, is characterized by tidal channels with bars and, from high elevation to low elevation, levee crests (LC), high (HAM) and low (LAM) algal marshes on the levee backslopes, and shallow mangrove ponds (MP). The LCs are draped with thin mats formed by filamentous Schizothrix cyanobacteria, display a low diversity of grasses, and are rarely bioturbated. LCs are rippled and mudcracked when overbank silts and sands accumulate on the mats after large tides. HAMs and LAMs are dominated by Scytonema mats, have a higher diversity of grasses and a greater abundance of mangroves, and are only weakly bioturbated by Marphysa worms. MPs contain abundant mangroves and are colonized by a low diversity assemblage of Cerithid gastropods, Geloina bivalves, Peneroplis foraminifera, and burrowing worms and crabs. The stratigraphic thickness of Holocene mud in this belt ranges from $1 \mathrm{~m}$ on the landward edge to $2.5 \mathrm{~m}$ at the beach. Radiocarbon ages from foraminifera tests from seven widely-spaced strati- 


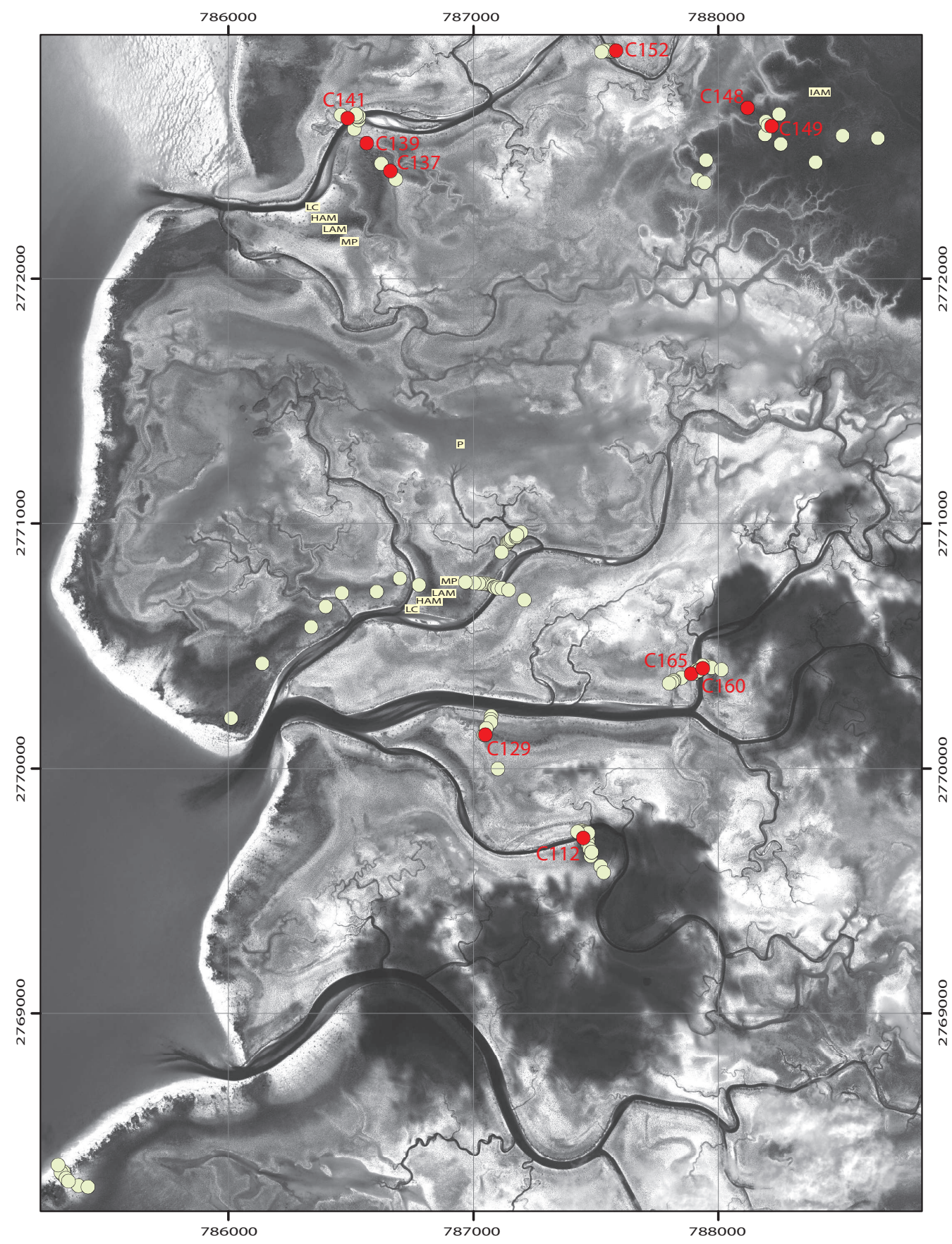

Figure 2. Panchromatic Quickbird image of Triple Goose Creek (Fig. 1). Core locations are marked with pale yellow circles. Sample locations are marked with red circles and red labels. Some characteristic geobiological facies are labeled, with LC-levee crest, HAM-high algal marsh, LAM-low algal marsh, MP-shallow mangrove pond, P-deep pond, IAM-inland algal marsh. 
graphic cores indicate that carbonate mud at TGC has accumulated over the last $\sim 1000$ years (Maloof and Grotzinger, in prep.).

The topographic relief that defines the geobiological zonation in the intertidal zone ranges from $0.5 \mathrm{~m}$ above mean tide level (MTL) for high LCs to $0.2 \mathrm{~m}$ above MTL for high MPs, to $0.5 \mathrm{~m}$ below MTL for some of the deeper ponds, to $1.5 \mathrm{~m}$ below MTL for some of the deeper channel bottoms. The mean high tide level (MHTL) corresponds approximately to the intersection between LAM facies and MP facies. Sediment above MHTL is nearly always white and usually laminated, while sediment below MHTL is bioturbated and nearly always dark grey. The mean annual tidal range at TGC dampens quickly as the tidal wave flows up-channel, with tidal ranges of $46 \mathrm{~cm}$ at the channel mouths, $29 \mathrm{~cm}$ in the western ponds, $18 \mathrm{~cm}$ at 2-3 $\mathrm{km}$ up-channel, and $\sim \mathrm{cm}$ at $4-5$ km up-channel (Hardie, 1977).

As part of a larger project studying the nature and time scale of channel migration in the intertidal zone of TGC (Maloof and Grotzinger, in prep.), we conducted five weeks of cm-scale topographic surveying coupled to surface geologic observations of sediment composition, sedimentary structures, and microbial and plant ecology. We also took more than 200 piston-cores (Fig. 2) and developed a Holocene stratigraphy of TGC referenced to approximate MTL, as determined by observations of water level. All the geochemical, rock magnetic, and paleomagnetic samples we discuss in this paper were collected in the context of this larger topographic, geobiologic and stratigraphic survey and are presented here to demonstrate the role of sedimentary iron cycling in the origin and fidelity of magnetic remanence in peritidal carbonates.

\section{Methods}

\subsection{Sample Collection}

We took over 500 samples during two field seasons in March and December 2005. We collected oriented surface samples (upper $2 \mathrm{~cm}$ ) by pressing open $7 \mathrm{~cm}^{3}$ plastic boxes (Natsuhara Gaiken, Osaka, Japan) vertically down into the mud until the boxes were full. The sharp edges of the boxes allowed us to retrieve undeformed samples. We oriented the samples using a magnetic compass and employed a sun compass to calculate local magnetic declination and check for orientation errors.

For subsurface samples, we extracted $5 \mathrm{~cm}$ diameter oriented cores ranging from $0.5-2.5 \mathrm{~m}$ in length using a stainless steel and aluminum Livingstone piston corer from the University of Minnesota Limnology laboratory. We kept vertical orientation marks on the corer aligned with an orientation mark on the ground surface. When we extruded each core, we used a plastic tool attached to the end of the corer to etch a line parallel to the orientation marks. Cores weresampled with respect to this orientation line usingplastic boxes. Using this coring method, we were able to take consistently vertical cores, but azimuthal core orientations were less reliable. We tape-sealed plastic boxes to prevent desiccation during transport, and kept samples refrigerated whenever possible. 
We group cores based on the surface facies. Five cores were used for rock magnetic and FMR measurements: C129 (LAM), C139 (HAM), C149 (IAM), C160 (LC), and C165 (MP). Five cores were used for paleomagnetic measurements: C112 (MP), C137 (LAM), C141 (LC), C148 (IAM), and C152 (MP), along with subsamples of C160 and C165. C130 and C148 were studied in the field using microelectrodes. We measured the acid insoluble fraction of C139 and C149 (see Fig. 2 for core locations).

\subsection{Geochemical measurements}

Oxygen and hydrogen sulfide concentrations were determined using OX100 and H2S500 microelectrodes (Unisense, Aarhus, Denmark). The microelectrodes were calibrated following manufacturer's instructions using solutions of the same salinity and temperature as the porewaters examined (35 psu and $\sim 29^{\circ} \mathrm{C}$ ). For the oxygen microelectrode, we calibrated between an aerobic end member (vigorously aerated seawater at ambient temperature) and an anaerobic end-member $(0.25 \mathrm{M}$ $\mathrm{NaCl}, 0.1 \mathrm{M} \mathrm{Na}$-ascorbate, and $0.1 \mathrm{M} \mathrm{NaOH}$ with tetrafluoroethane in the headspace). $\left[\mathrm{O}_{2}\right]$ for water saturated at 1 bar total pressure, $29^{\circ} \mathrm{C}$, and $\sim 35$ psu salinity is $194 \mu \mathrm{M}$. The lower detection limit for $\left[\mathrm{O}_{2}\right]$ is $\sim 2 \mu \mathrm{M}$. The sulfide microelectrode was calibrated using serial dilutions (1-100 $\mu \mathrm{M})$ of a $1 \mathrm{mM}$ stock solution of sodium sulfide. The stock solution was made in $\mathrm{pH} 2$ buffer reduced by bubbling with tetrafluoroethane and the addition of $1 \mathrm{mM} \mathrm{TiCl}_{3} \cdot \mathrm{pH}$ was measured with each sulfide measurement to convert measured $\mathrm{H}_{2} \mathrm{~S}$ to total sulfide $\left(\mathrm{TS}=\mathrm{H}_{2} \mathrm{~S}+\mathrm{HS}^{-}+\mathrm{S}^{2-}\right.$ ). In addition to $\mathrm{C} 130$ and $\mathrm{C} 148$, we made microelectrode measurements through $\sim 3 \mathrm{~cm}$ of Scytonema mat near C130 and Schizothrix-bearing LC surface sediments.

The acid insoluble fraction of sediments was determined by air-drying 500-1500 mg of sediment, dissolving the sample by drop-wise addition of $6 \mathrm{~N} \mathrm{HCl}$, allowing the sample to sit for $\sim 12$ hours, centrifuging the remaining pellet of material and washing it twice, then air-drying the pellet and measuring its mass.

\subsection{Paleomagnetic and Rock Magnetic Measurements}

Paleomagnetic measurements and room-temperature rock magnetic experiments were conducted using a 2G SQUID Magnetometer equipped with in-line alternating field (AF) demagnetization coils, isothermal remanent magnetization (IRM) pulse coils, and an anhysteritic remanent magnetization (ARM) biasing field coil housed in a magnetically shielded room. Paleomagnetic measurements were made on samples in plastic core boxes. A subset was then subjected to three-axis AF demagnetization in logarithmic steps to a maximum field strength of $85 \mathrm{mT}$. Magnetic components were analyzed for each sample in Paleomag 3.1 (Jones, 2002) using principal component analysis (Kirschvink, 1980).

Rock magnetic experiments were conducted on $\sim 300-500 \mathrm{mg}$ of freeze-dried sediment powders in quartz glass EPR tubes using procedures described in (Kopp et al., 2006a). Starting with an AF-demagnetized sample, vertical ARMs were imparted in $100 \mathrm{mT}$ alternating fields with DC 
biasing fields increased in $50 \mu \mathrm{T}$ steps up to $1 \mathrm{mT}$ and then demagnetized. ARM susceptibility was determined from the ARM acquired in a $100 \mu \mathrm{T}$ biasing field. For comparison with the ARM, the sample was given an IRM in a $100 \mathrm{mT}$ pulse field, and then demagnetized. Finally, the sample was given IRMs progressively up to $350 \mathrm{mT}$, and the final, nearly saturated IRM was demagnetized stepwise. To produce coercivity spectra from the stepwise IRM data, we take the derivative of moment with respect to the logarithm of the applied field.

We report the following parameters: IRM, determined at the maximum applied field strength of $350 \mathrm{mT}$; the coercivity of remanence $B_{c r}$ and crossover interaction indicator $R$, determined from the intersection of the stepwise IRM acquisition and AF demagnetization curves (Cisowski, 1981); and the ratio of ARM susceptibility to IRM measured in a $100 \mathrm{mT}$ field, $\chi_{\mathrm{ARM}} / \mathrm{IRM}$.

\subsection{Ferromagnetic resonance spectroscopy}

Ferromagnetic resonance (FMR) spectra were acquired from freeze-dried sediment samples using the technique described in Kopp et al. (2006b,a). For all samples, enough powder was placed in the EPR tubes to fill the spectrometer sample cavity; thus, all absorption strengths measured are effectively normalized to volume. To summarize spectral characteristics, we use the following empirical parameters of Weiss et al. (2004): the effective $g$-factor of maximum absorption $g_{\text {eff }}$, the asymmetry ratio $A$, and the full-width at half-maximum $\triangle B_{F W H M}$.

FMR spectra also carry information about electron paramagnetic resonance (EPR). Following Crook et al. (2002), we assessed the relative abundance of paramagnetic Fe(III) in different samples by measuring the height of the $g=4.3(\sim 160 \mathrm{mT})$ peak above a baseline, which we approximated by linear interpolation between the $120 \mathrm{mT}$ and $230 \mathrm{mT}$ points in the derivative absorption spectra. To assess the relative abundance of $\mathrm{Mn}(\mathrm{II})$, we measured the height between the maximum and the minimum of the sixth line of the Mn(II) sextet.

To guide detailed interpretation of spectral shapes, we modeled the data as described in Kopp et al. (2006a). To reduce the impact of paramagnetic components on the fits, we eliminated the $\mathrm{Fe}$ (III) peak by linear interpolation between 120 and $230 \mathrm{mT}$ and smoothed out $\mathrm{Mn}$ (II) peaks and other narrow peaks using the robust LOWESS method (Cleveland, 1979) with a $30 \mathrm{mT}$ window. Each fit component can be described by three parameters: the true $g$-factor $g$, the anisotropy field $B_{a n}$, and a Gaussian broadening factor $\sigma$. Because of the complexity of natural samples, we used only components with first-order uniaxial anisotropy and varied the number of fit components. To determine whether we were reaching global or local fit optima, we also varied the initial fit parameters. Different initial parameters generally produced different fit optima, so we employ the fit solutions as qualitative guides to spectrum interpretation rather than as true indicators of underlying physical parameters. 


\subsection{Electron microscopy}

Samples were prepared for analysis with a transmission electron microscope (TEM) using two methods. The first method involved separating magnetic materials with a strong magnet following the procedure of Petersen et al. (1986). Separates were transferred onto carbon film supported $\mathrm{Cu}$ TEM grids. In the second method, core samples were fixed with $2.5 \%$ glutaraldehyde in $0.1 \mathrm{M}$ sodium cacodylate buffer and washed with $100 \%$ ethyl alcohol. Thin slices from the cores were embedded in epoxy resin to preserve biological components associated with magnetic material. Ultrathin sections (70-80 nm thick) were cut using a diamond knife and transferred to carbon film supported $\mathrm{Cu}$ TEM grids (Vali et al., 2004). Samples were imaged and analyzed using a JEOL JEM-2000FX TEM with a Quartz XOne microanalytical system.

\section{Results}

\subsection{Ferromagnetic resonance and rock magnetic data}

Both IRM and total FMR absorption measure the total amount of ferromagnetic material in a sample. Variability in these parameters through a core reveals first-order changes in magnetic mineralogy. Changes in the ratio of IRM to FMR absorption reflect the differing sensitivities of the two techniques. IRM strength excludes particles with coercivities greater than the maximum applied field and, more importantly in these samples, superparamagnetic particles with an unblocking time shorter than the $\sim 30$ s measurement time. FMR, in contrast, detects particles with sub-nanosecond unblocking times, reflecting the $9.8 \mathrm{GHz}$ frequency of the microwave source.

All cores, regardless of facies, experience a significant decrease in ferromagnetic material at a depth near or above the mean tide level (Fig. 3, 4). Above the drop-off, IRM strengths range from $15-53 \mu \mathrm{Am}^{2} / \mathrm{kg}$, while below the drop-off, IRM plunges to $2-6 \mu \mathrm{Am}^{2} / \mathrm{kg}$. Total FMR absorption also decreases at this transition, but by a lesser degree, which reflects an increase in the proportion of superparamagnetic and/or high coercivity particles.

In three of the five cores analyzed (C129, C149, and C160), all from algal marsh or levee crest facies, total FMR absorption and IRM strength exhibit a moderate increase in the lower portion of the submerged and bioturbated depths of the cores. In C149 and C160, IRM reaches values of $11-16 \mu \mathrm{Am}^{2} / \mathrm{kg}$. In $\mathrm{C} 129$, recovery in IRM is modest. In all three cores, the recovery is more pronounced in total FMR absorption, which reflects an IRM/FMR absorption ratio similar to or slightly higher than that in the magnetic minimum zone. The magnetic recovery is therefore fueled by a process that produces predominantly superparamagnetic grains.

In all cores, the magnetic drop-off coincides with a $\sim 10-20 \mathrm{mT}$ increase in $B_{c r}$, to $\sim 50-60 \mathrm{mT}$. Despite the coercivity increase, coercivity remains too low to indicate a significant role for highcoercivity phases such as hematite or goethite. Rather, it suggests that the decrease in magnetization 

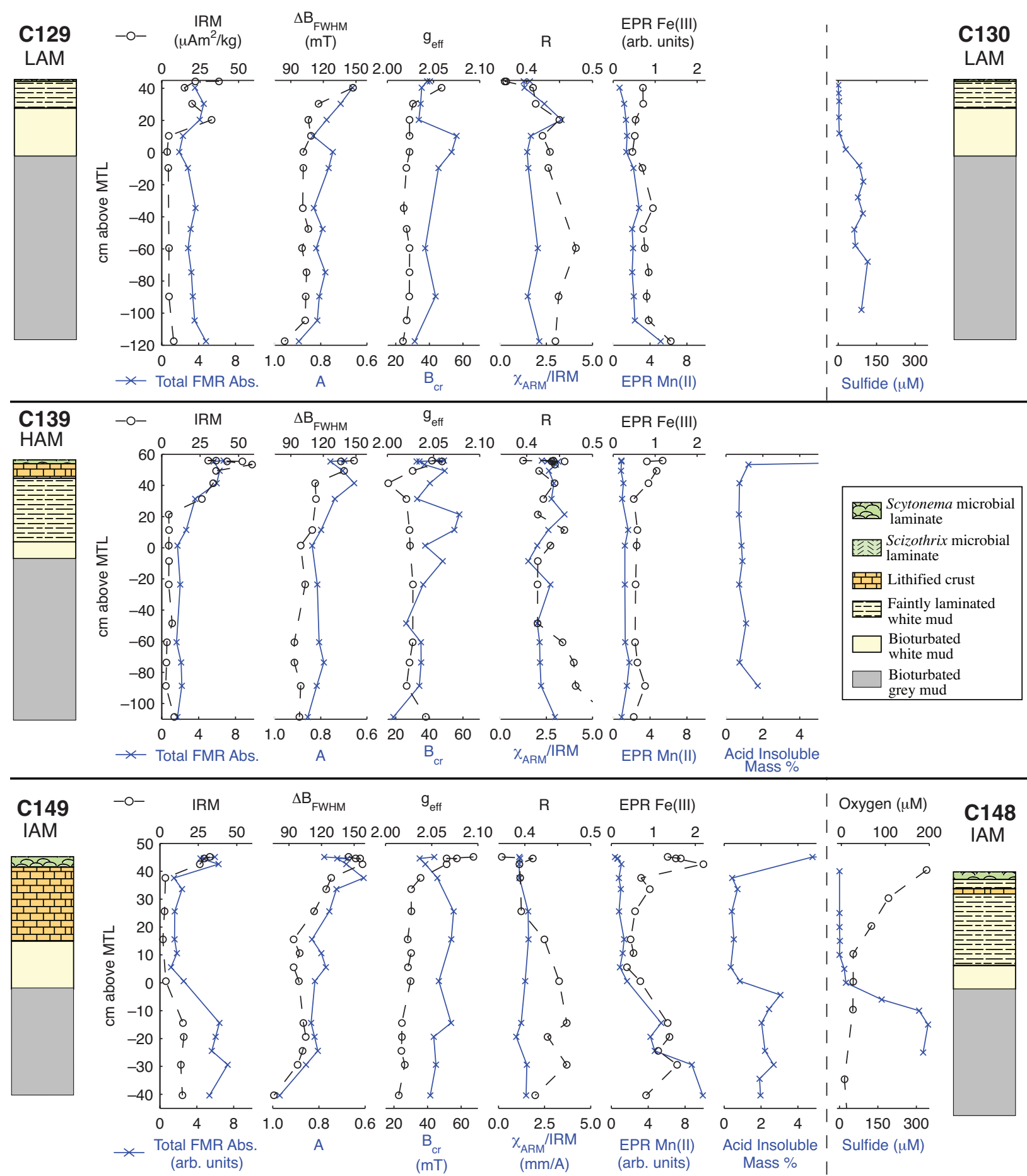

EPR Fe(III)

| Oxygen $(\mu \mathrm{M})$

C148 $0 \quad 1 \quad 2$

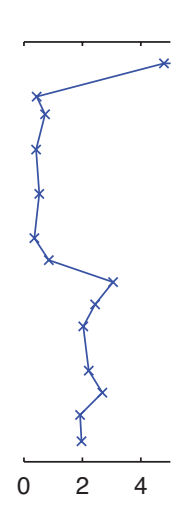

0
1
1
$*$
$*$
$*$ $\begin{array}{llll}0 & 100 \quad 200 & \text { IAM }\end{array}$
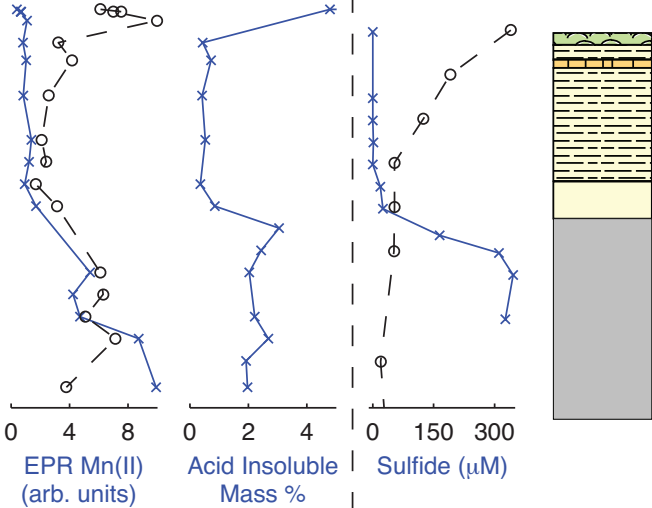

Figure 3. Stratigraphic columns and profiles of magnetic and ferromagnetic resonance parameters through algal marsh cores C129, C139, and C149, and microelectrode data from C130, adjacent to C129, and C148, near C149. 


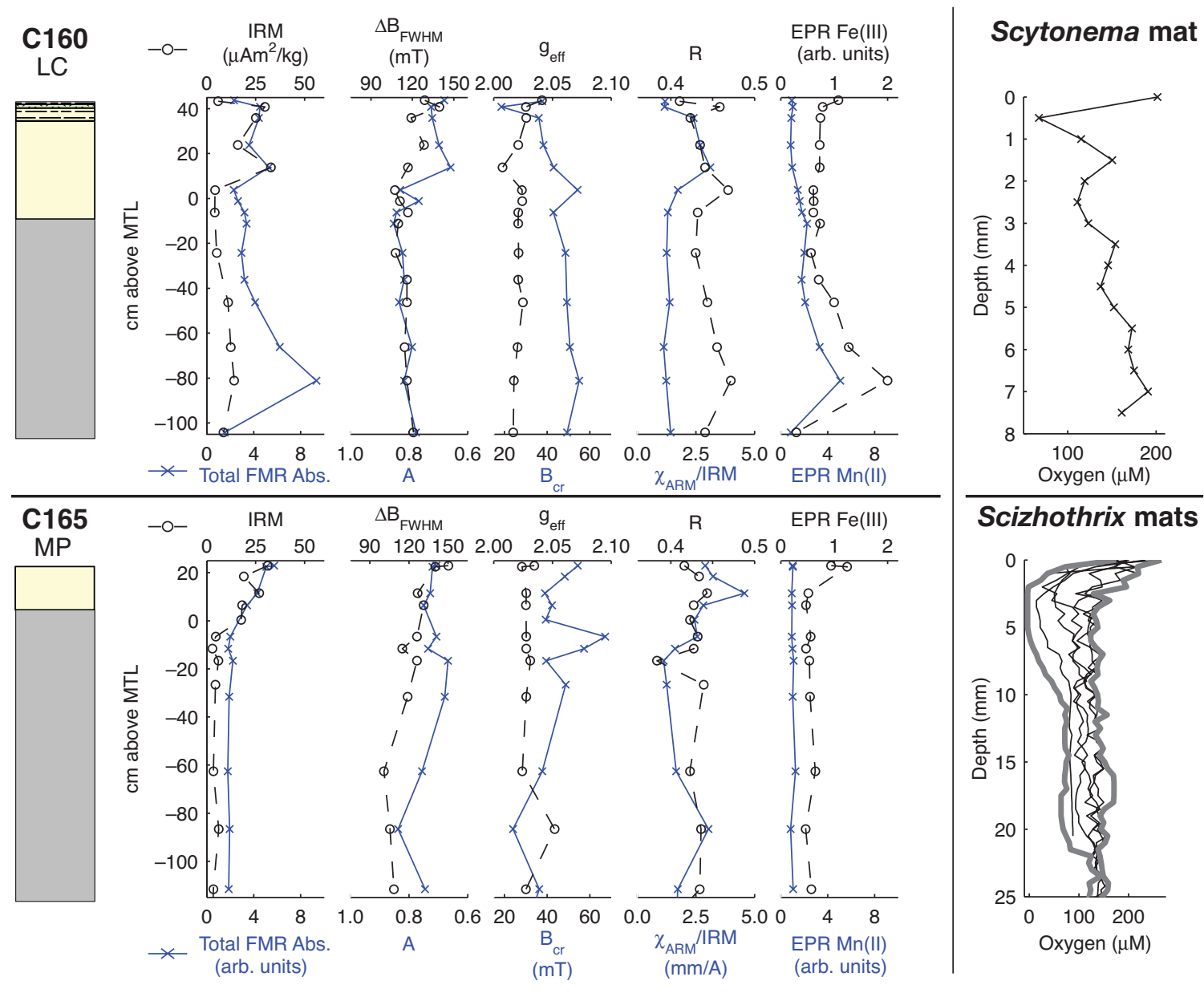

Figure 4. Stratigraphic columns and profiles of magnetic and ferromagnetic resonance parameters through levee crest core C160 and mangrove pond core C165, and mm-scale oxygen profiles through Scytonema and Schizothrix mats. The Scytonema profile was measured near C130. The Schizothrix profiles were measured at different patches of a single levee crest site. The thick grey lines in the Schizothrix plot represent the upper and lower bounds of measured oxygen levels. Facies legend as in Fig. 3.

is due to a preferential loss of the lowest coercivity portion of the particles. As the change in IRM/FMR absorption ratios indicate that this loss occurs simultaneously with the precipitation of new superparamagnetic particles, the return to lower coercivity farther down core may reflect the growth of these new superparamagnetic particles into the low coercivity region of the single domain field.

ARM/IRM ratios vary considerably between cores. In three of the cores (C129, C160, and C165), ARM/IRM ratios peak just above the magnetic drop-off. In C139, ARM/IRM ratios are high throughout, while in C149, they are more subdued.

Particulate $\mathrm{Mn}(\mathrm{II})$, presumably present as a constituent of carbonate and sulfide phases, is consistently low above the magnetic drop-off. Though the change in raw Mn(II) concentrations at the drop-off is generally slight, the drop-off itself produces a 2-3 fold increase in Mn(II)/Total FMR Absorption ratios. This enhanced $\mathrm{Mn}$ (II)/Absorption ratio remains nearly constant throughout the lower portion of the core, which suggests that the process producing a magnetic recovery in some 

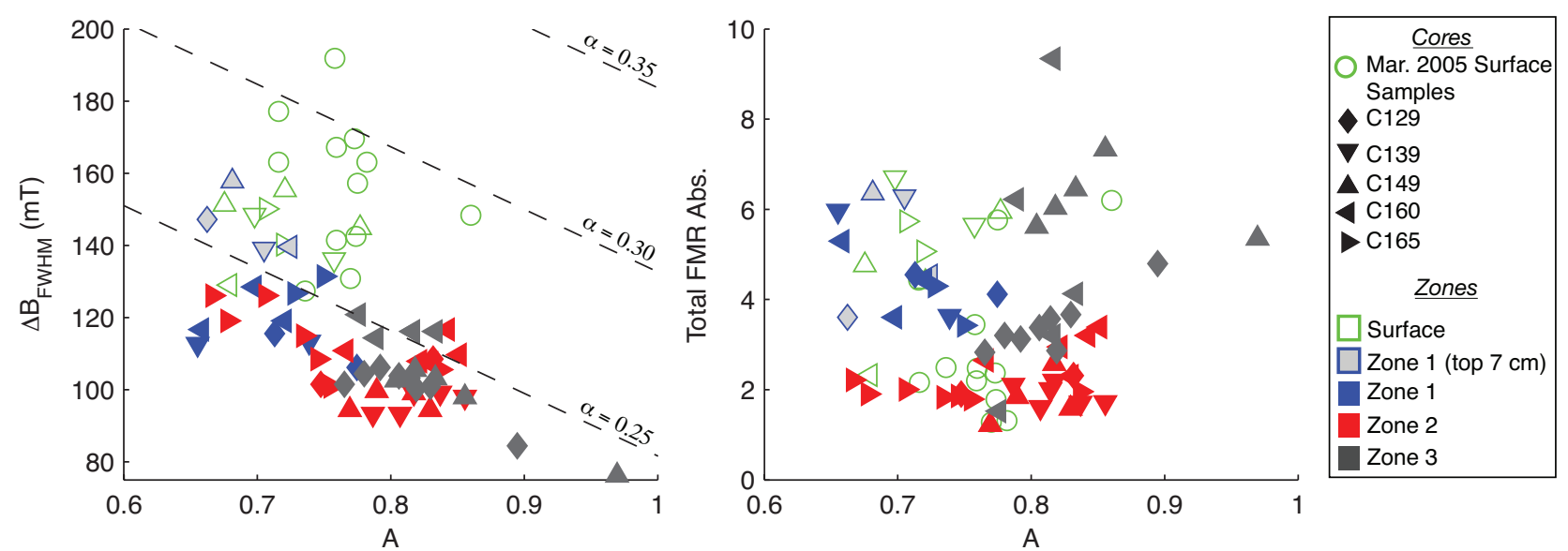

Figure 5. Crossplots of FMR spectral full-width at half-maximum ( $\triangle B_{F W H M}$, left) and total ferromagnetic resonance absorption (right) against the FMR asymmetry parameter $A$, defined as the ratio of the high-field half-width at half-maximum to the low-field half-width at half-maximum. Symbol shapes represent different cores, while colors represent sample depth, described with reference to the zones defined in the text. Dashed diagonal lines on the left plot contour constant values of the $\alpha$ parameter of Kopp et al. (2006b). Depths of the zones in each core are shown in Figure 9.

of the cores is also producing particulate Mn(II). The adsorption of Mn(II) onto iron sulfide minerals, such as mackinawite and the ferrimagnetic mineral greigite, is a likely candidate (Arakaki and Morse, 1993).

For surface samples, the empirical FMR asymmetry parameter $A$ and width parameter $\Delta B_{F W H M}$ define a broad field, with $A$ from 0.68 to 0.86 and $\triangle B_{F W H M}$ from 129 to $191 \mathrm{mT}$ (Fig. 5). Samples from the top $7 \mathrm{~cm}$ of the cores fall at the low $\triangle B_{F W H M}$ end of this range, but almost all the surface samples have broader spectra than deeper core samples. Deeper samples fall in a more narrow field of $\Delta B_{F W H M}$ vs. $A$ space, with samples from the oxic sediments above the magnetic drop off generally slightly broader and more asymmetric than deeper samples. The magnetically depleted samples span a fairly broad range of asymmetry values, while samples from the lower magnetically enriched zone are less asymmetric than those from the upper magnetically enriched zone and overlap with the less asymmetric samples from the magnetically depleted zone.

\subsection{Geochemical Data}

The formation of magnetic minerals in sediments is linked to stratigraphic redox gradients set by oxygen and sulfide. Oxygen microelectrode measurements taken in daylight at $500 \mu \mathrm{m}$ intervals through Scytonema mats at the top of algal marsh sediments and Schizothrix-bearing laminated levee crest sediments indicate the presence of oxygen-depleted microenvironments within the uppermost sediments (Fig. 4). In one example, Schizothrix-bearing sediments became fully anoxic $\left(\left[\mathrm{O}_{2}\right]<5 \mu \mathrm{M}\right) 2 \mathrm{~mm}$ below the surface, while returning to only moderately depleted oxygen levels by $11 \mathrm{~mm}$ depth. Other transects through Schizothrix-bearing sediments in the same area found $\left[\mathrm{O}_{2}\right] \geq 110 \mu \mathrm{M}$ at all depths, which highlights the small-scale spatial variability. Our transect through a Scytonema mat found $\left[\mathrm{O}_{2}\right]$ varying between $\sim 70$ and $\sim 200 \mu \mathrm{M}$. We emphasize that all 
our measurements were taken during the day; at night, when photosynthetic oxygen production in the mats ceases, oxygen levels should be significantly lower (Jørgensen et al., 1979).

We performed microelectrode measurements of sulfide on C130, immediately adjacent to C129, and $\mathrm{C} 148$, located proximal to $\mathrm{C} 149$. We also made microelectrode $\mathrm{O}_{2}$ measurements and litmus paper $\mathrm{pH}$ measurements of $\mathrm{C} 148$. In $\mathrm{C} 130$, sulfide concentrations are $<1 \mu \mathrm{M}$ in the upper $30 \mathrm{~cm}$ ( $>12 \mathrm{~cm}$ above MTL), then increase between $12 \mathrm{~cm}$ above MTL and $8 \mathrm{~cm}$ below MTL to about 80 $\mu \mathrm{M}$. The concentration remains between 60 and $120 \mu \mathrm{M}$ throughout the remainder of the core. The start of the increase in sulfide concentrations coincides with the magnetic drop-off in C129, while the stabilization of sulfide concentrations at high levels coincides with the magnetic recovery.

In $\mathrm{C} 148,\left[\mathrm{O}_{2}\right]$ falls below $30 \mu \mathrm{M}$ over the upper $20 \mathrm{~cm}$ (>20 cm above MTL), while sulfide concentrations first exceed $10 \mu \mathrm{M}$ at $5 \mathrm{~cm}$ above MTL and climb to values in excess of $200 \mu \mathrm{M}$ by $10 \mathrm{~cm}$ below MTL. pH values are 7.2 in the top $20 \mathrm{~cm}$, fall to 7.0 between 25 and $30 \mathrm{~cm}$, and stabilize around 7.5 farther down the core. These data suggest that the recovery of magnetization starting around MTL in C149 correlates with the onset of sulfidic conditions.

Due to absence of clastic materials, measurements of the fraction of sediment mass composed of acid insoluble material provide estimates of the amount of organic matter. We measured the acid insoluble fraction in sediments from two algal marsh cores: C149, which has a lower zone of relatively high magnetization, and $\mathrm{C} 139$, which does not. In both cores, the uppermost samples, containing visible mat material, were organic rich, consisting of $4-13 \%$ by mass acid insoluble material. The amount of organic matter rapidly decays with depth, and is generally < 1\% in C139 and in C149 above the lower zone of relatively high magnetization. In the lower zone of relatively high magnetization in C149, the acid insoluble content is 2-3\% by weight. Throughout C149 and in $\mathrm{C} 139$ below $65 \mathrm{~cm}$, mangrove root fragments are a visually identifiable component of the acid insoluble fraction.

\subsection{FMR and coercivity spectra}

Component analysis of FMR and coercivity spectra help identify different major magnetic components in sediments. Both visual inspection and non-linear least squares fitting reveal the presence of two paramagnetic components and at least three ferromagnetic components in the FMR spectra of the carbonate muds (Fig. 6). Two ferromagnetic components and both paramagnetic components are present in all samples; the third ferromagnetic component is present above the magnetic drop-off.

The two paramagnetic components are a singlet peak centered at $g=4.3(\sim 160 \mathrm{mT})$ and a complicated set of peaks between $\sim 320$ and $\sim 380 \mathrm{mT}$, centered at $g=2.00$. The peak at $g=4.3$ represents paramagnetic $\mathrm{Fe}(\mathrm{III})$, likely present primarily in clay minerals. The set of peaks around $g=2.00$ primarily represents $\mathrm{Mn}(\mathrm{II})$, although it may also include contributions from the singlet peaks of free radicals in organic carbon and free electron centers in carbonates.

A narrow, slightly high-field extended ferromagnetic component, centered at $\sim 350 \mathrm{mT}$ and with 

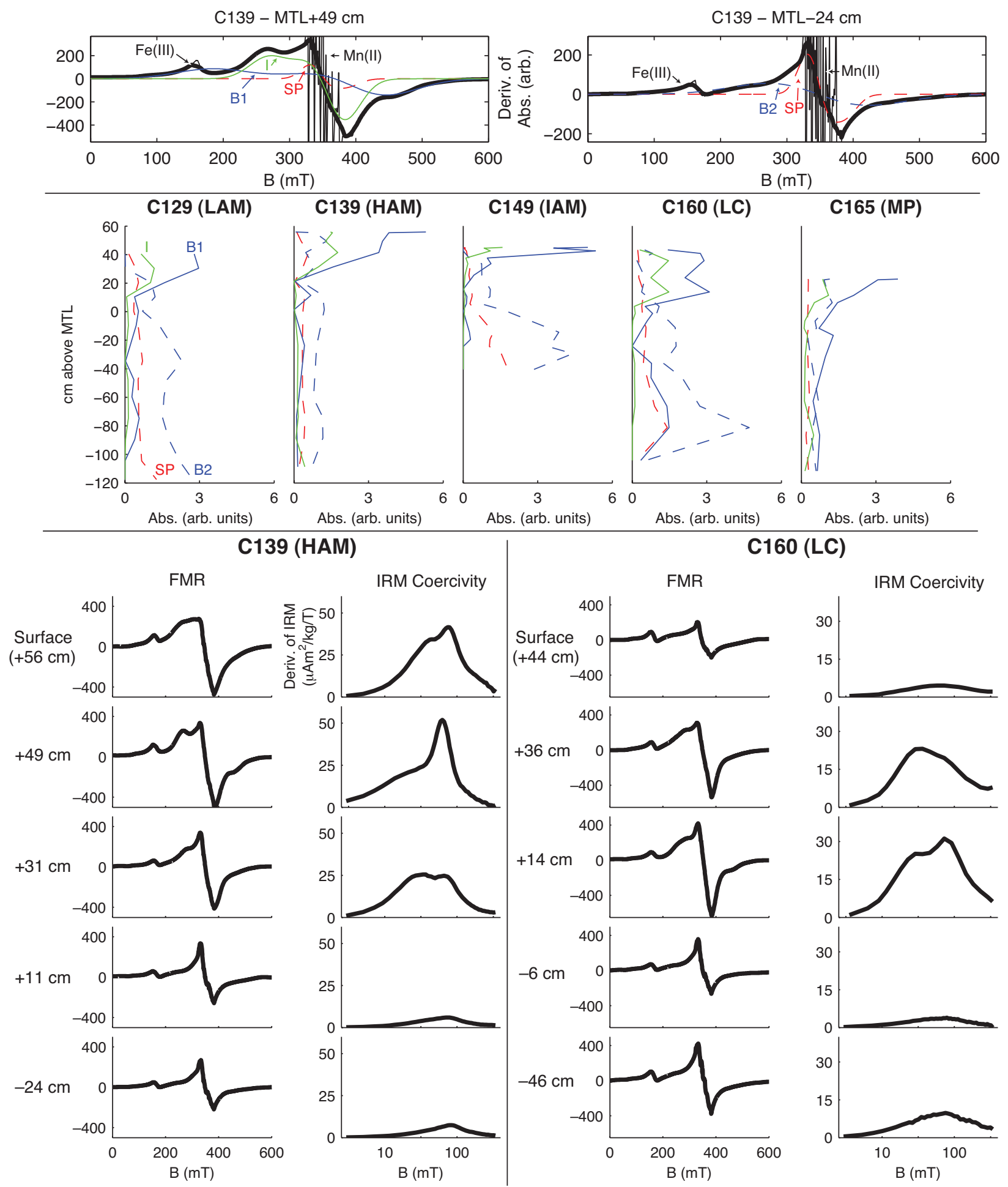

Figure 6. (Top) Smoothed (heavy line) and unsmoothed (thin line) FMR derivative absorption spectra for C139 samples from $49 \mathrm{~cm}$ above and $24 \mathrm{~cm}$ below MTL. Colored lines show fitted components: a narrow ferromagnetic peak associated with superparamagnetic particles (SP), an intermediate width component attributable to magnetotactic bacteria (I), a broad component with asymmetry suggesting a contribution from magnetotactic bacteria (B1), and a broad symmetric component (B2). Paramagnetic absorptions are also labeled. (Middle) Profiles showing approximate contributions of each component to total FMR absorption in each core, calculated by fitting each spectrum to a linear combination of end-members with spectral parameters fixed in the center of the range typical for each component. (Bottom) Selected FMR spectra and IRM acquisition coercivity spectra from cores $\mathrm{C} 139$ and C160. 
$g_{\text {eff }}$ of $\sim 1.99$ and $\Delta B_{F W H M}$ of $\sim 60 \mathrm{mT}$, is present in varying degrees in all spectra (Fig. 6, comp. SP). It is generally possible to obtain well-constrained fit parameters for this component; typical best-fit parameters are $g=1.97, B_{a n}=-33 \mathrm{mT}$, and $\sigma=17 \mathrm{mT}$. Anisotropy fields of this magnitude suggest room-temperature remanent coercivities less than $10 \mathrm{mT}$ (Kopp et al., 2006a) and are consistent with those expected for very fine grained, predominantly superparamagnetic ferrimagnetic particles.

A broad ferromagnetic component, with $\triangle B_{F W H M}$ of $\sim 200 \mathrm{mT}$ and generally centered between $\sim 330$ and $\sim 370 \mathrm{mT}$, is also present in varying degrees in all spectra. The nature of this broad component varies between samples, however. In samples taken above the magnetic drop off, it is usually possible to obtain consistent fit parameters; typical values are $g=2.15-2.25, B_{a n}=100-200$ $\mathrm{mT}$, and $\sigma=50-100 \mathrm{mT}$ (Fig. 6, comp. B1). Thus, in the upper sediments, the broad component has a slight low-field extended asymmetry. This asymmetry suggests that elongate magnetite particles produced by magnetotactic bacteria may contribute to the broad signal (Kopp et al., 2006a). In contrast, the broad signal below the magnetic drop-off is more nearly symmetric and therefore consistent with ferrimagnetic particles capable of carrying a stable remanence and exhibiting only limited magnetostatic interactions (Fig. 6, comp. B2). Typical fit parameters are $g=1.90-2.10$, $\left|B_{a n}\right|<30 \mathrm{mT}$, and $\sigma=70-90 \mathrm{mT}$.

A ferromagnetic component of intermediate width is usually present in sediments above the magnetic drop off (Fig. 6, comp. I). The intermediate component exhibits low-field extended asymmetry and $\triangle B_{F W H M}$ of $\sim 100 \mathrm{mT}$. This component generally yields fit parameters with $g$ between 2.05 and 2.16, $B_{a n}$ between 50 and $75 \mathrm{mT}$, and $\sigma$ between 20 and $30 \mathrm{mT}$. These characteristics resemble those of chains of nearly equidimensional magnetite particles produced by magnetotactic bacteria (Kopp et al., 2006b,a).

The coercivity spectra in general take the form of broad, approximately Gaussian peaks with maxima between $\sim 35$ and $\sim 75 \mathrm{mT}$ (Fig. 6). However, a few samples have two clearly distinct coercivity peaks, one centered around $30 \mathrm{mT}$ and another centered around 60-75 mT. These samples (20-30 $\mathrm{cm}$ above MTL in C129, 31-49 $\mathrm{cm}$ above MTL in C139, 14-24 $\mathrm{cm}$ above MTL in C160, and at MTL in C165) all come from sediments above the magnetic drop-off. The clarity and median values of the dual peaks suggest magnetic carriers with narrowly defined population characteristics, as would be expected from magnetite produced by magnetotactic bacteria. The locations of the two peaks is consistent with the lower peak representing equidimensional magnetosomes and the higher peak represent elongate magnetosomes (Kopp et al., 2006a).We caution that this interpretation is by no means unique, and it is unlikely that magnetosomes would be the only source of magnetite in these sediments. Nonetheless, in agreement with a previous electron microscopy and rock magnetic study of a single surface sample from northwest Andros Island (McNeill, 1990), both the coercivity spectra and the FMR spectra support a major role for magnetotactic bacteria in producing magnetite in the upper portion of the sediment columns. 


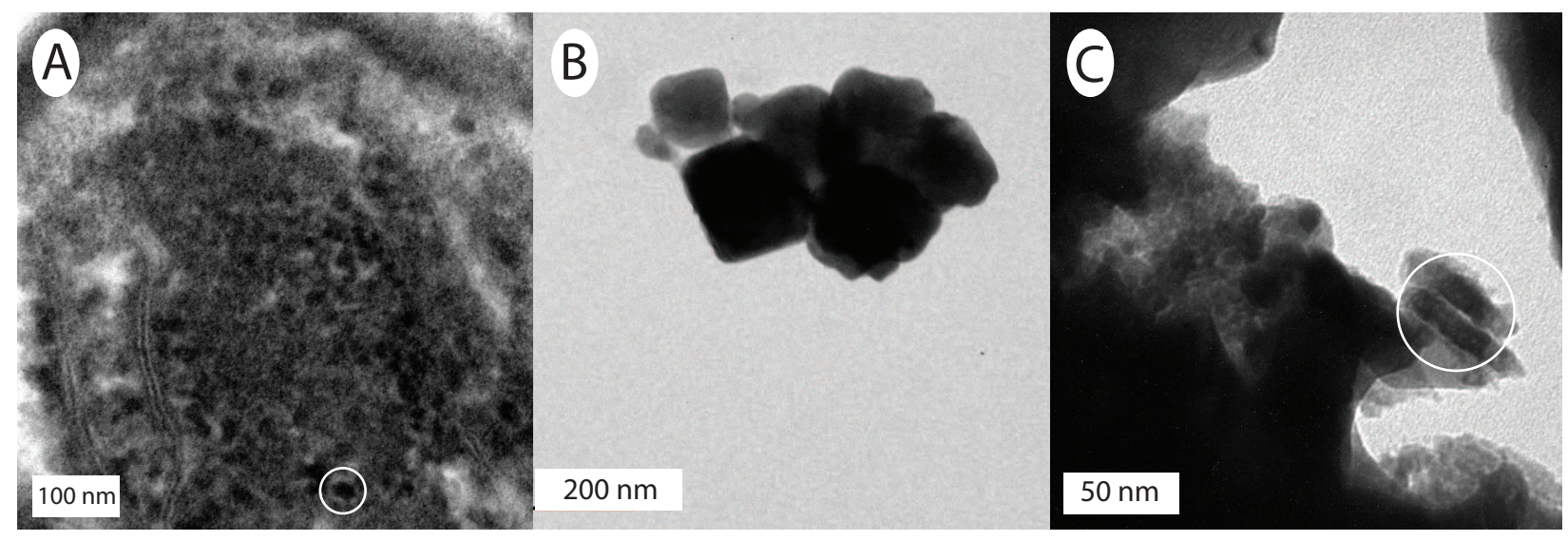

Figure 7. TEM images of (A) superparamagnetic magnetite particles within an organic matrix from above MTL in C139 (HAM), (B) single domain stoichiometric magnetite particles from surface samples at C6 (LC), and (C) elongate magnetic iron sulfide particles resembling greigite from $20 \mathrm{~cm}$ below MTL in C149 (IAM). White circles in (A) and (C) show representative particles of SP magnetite and iron sulfide, respectively. White areas in ultrathin sections are holes where primary aragonite has dissolved when exposed to water during sample preparation.

\subsection{Electron microscopy}

The most abundant magnetic component inimaged samples is superparamagnetic (SP) magnetite (Fig. 7A). SP magnetite is predominantly associated with Fe-rich clay minerals or with biomass containing remnant cellular structures. In both cases, the SP magnetite is similar to magnetite produced extracellularly by microbial Fe reduction (e.g., Li et al., 2004). Aggregates of cuboidal single domain (SD) magnetite, similar in size and aspect-ratio to that produced by magnetotactic bacteria, were found in some surface samples but were not abundant (Fig. 7B). In ultrathin sections prepared from core samples $20 \mathrm{~cm}$ below MTL in C149, aggregates of iron sulfides were present (Fig. 7C). The aggregates contain nanosized crystals (Fig. 7C) that chemically and morphologically resemble soil greigite (Stanjek et al., 1994). We found no hematite, goethite or multi-domain magnetite.

In light of our FMR and magnetic data, we were surprised by our inability to image intact chains of bacterial magnetite in extracts. However, even the most magnetic of our samples are relatively weak. Well-preserved chains have been previously imaged in Cretaceous limestones with NRM intensities comparable to the intensities of our weakest samples Icitep\{Montgomery 1998\}. [NOT SURE what to say here - ADAM help.].

\subsection{Paleomagnetic Data}

We measured paleomagnetic direction in oriented carbonate samples to determine how different magnetic facies record the geomagnetic field. All 87 surface samples collected during the first field season preserved a natural remanent magnetization (NRM) indistinguishable from the local geomagnetic field (5-year IGRF). Stepwise AF-demagnetization of a 17 sample subset from this 
preliminary collection showed consistent linear decay to the origin and a high-AF direction indistinguishable from the NRM.

Most of the 154 samples (53 surface, 101 core) collected during the second field season did not have NRM directions colinear with the local geomagnetic field. 59\% required AF demagnetizing fields as large as $11 \mathrm{mT}$ to remove a fairly stable overprint direction before decaying linearly to the origin with further demagnetization (Supp. Fig. S1). Stable overprint directions form a random stereonet distribution (Fig. 8) and may have been acquired during airport security screening. HighAF directions from surface samples form a tight cluster with Fisher means overlapping the local IGRF (Fig. 8). High-AF directions from core samples form clouds with greater scatter. Core Fisher means display inclinations indistinguishable from the local IGRF, but tend to show a counterclockwise declination offset from the local IGRF of $10-60^{\circ}$. We attribute the systematic declination offset to difficulties keeping the azimuth of the circular corer aligned during each drive. Comparing NRM intensities after AF removal of the low-AF overprint to SIRM intensities after similar AF cleaning yields $\frac{S I R M}{N R M}$ ratios of 30 to 300 , consistent with a chemical, rather than detrital, origin of the high-AF remanence (Fuller et al., 2002).

Direct observations of the geographic position of the magnetic north pole since 1904 suggest that magnetic inclination at TGC should have reached values as high as $\sim 60^{\circ}$ in 1904 (compared to $55^{\circ}$ today). Archeomagnetic reconstructions spanning the last 2000 years suggest that magnetic inclination should have attained values as low as $32^{\circ}$ during the onset of carbonate sedimentation at TGC, $1000 \mathrm{CE}$ (Ohno and Hamano, 1992). Assuming a general sedimentation rate of $2 \mathrm{~mm} / \mathrm{yr}$ for a typical levee crest, consistent with our ${ }^{14} \mathrm{C}$ data and measured accumulation rates of 1-3 $\mathrm{mm} / \mathrm{yr}$ during dye experiments on levee crests (Hardie, 1977), we would expect to see an increase in inclination between 0 and $20 \mathrm{~cm}$ depth in an LC core and a steady decline in inclination from 20 to $200 \mathrm{~cm}$ depth.

Inclination data from the cores yield a mean of $\sim 54.6^{\circ}$ and are, in general, too variable to discern secular trends with depth. It is not surprising that the inclination peak in 1904 is not observed, as $\sim 5^{\circ}$ is within the range of the scatter we observe in our directions. However, if carbonate muds near the base of the sedimentary column were recording the syndepositional geomagnetic field, we would expect to see $>20^{\circ}$ shallowing with depth. The lack of a trend toward shallower inclinations likely indicates that physical and biogeochemical reworking of magnetic particles below MTL continues until the carbonates are actually cemented, and therefore carbonate muds deposited at 1000 $\mathrm{CE}$ have aligned themselves with the modern geomagnetic field. The stratigraphic changes with depth in bioturbation, geochemistry and rock magnetics described above do not have a discernible effect on magnetic direction, further supporting the idea that the entire Holocene sedimentary column is magnetized in the present local field.

\section{Discussion}

The magnetic and FMR data divide the sediment cores into three main zones: an upper zone of relatively high magnetization (Zone 1), a zone of low magnetization (Zone 2), and, in some cores, 

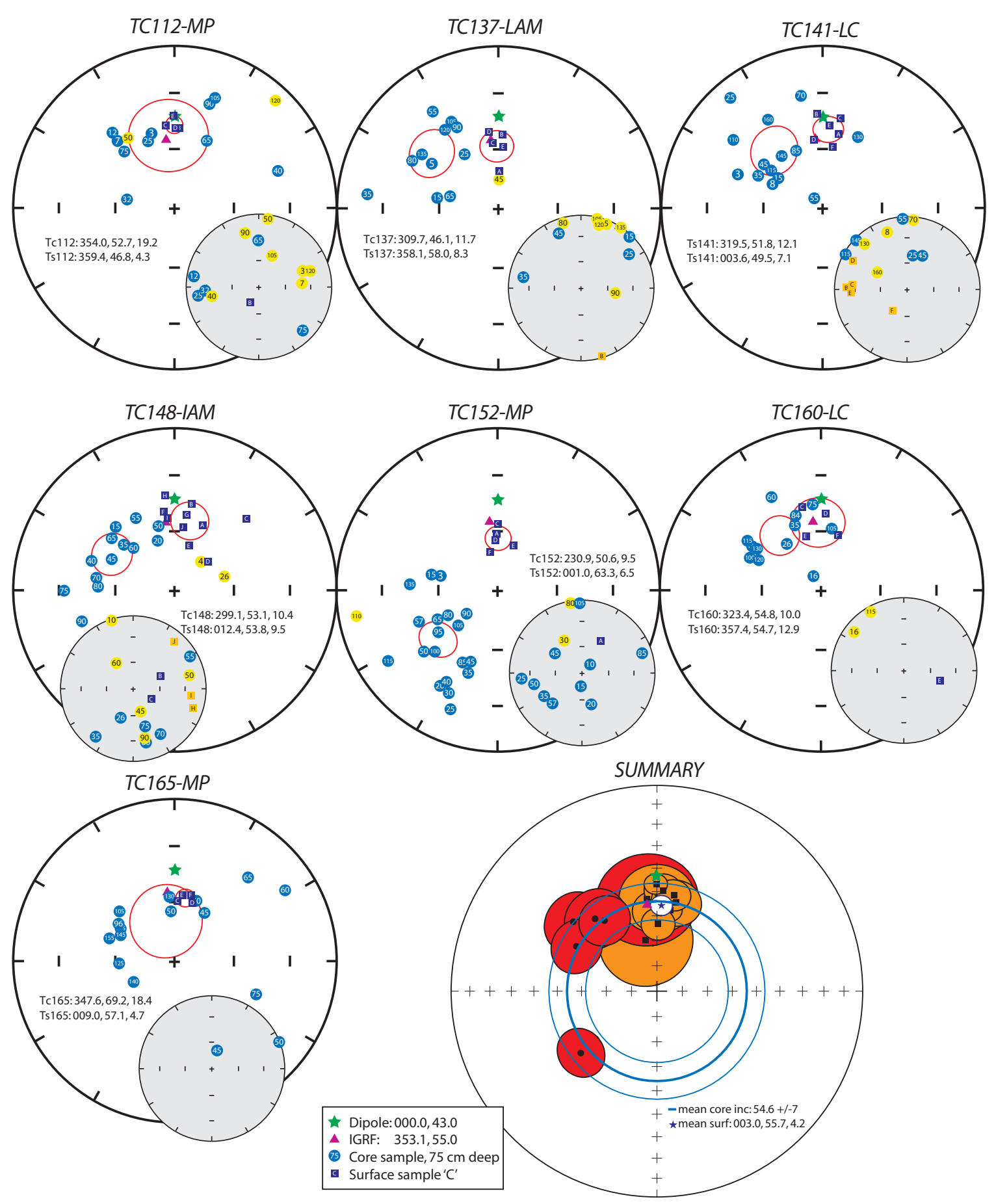

Figure 8. Equal-area stereonet projections of paleomagnetic directions from surface (TS) and core (TC) samples. Small grey stereonets collect overprint directions, and large white stereonets collect primary remanent magnetization directions. Blue/orange squares represent lower/upper hemisphere directions for surface samples from the facies and location of the associated core. Light blue/yellow circles represent lower/upper hemisphere directions for core samples, with the stratigraphic depth labeled in white/black text. The green star and purple triangle indicate the direction of the dipole field and the International Geomagnetic Reference Field (IGRF) for Triple Goose Creek, respectively. In the summary stereonet, fisher means for surface/core primary remanence directions are depicted with black squares/circles, and $\alpha_{95}$ uncertainties are depicted with orange/red circles. The Fisher mean of the surface site means is drawn as a purple star with a white $\alpha 95$ uncertainty ellipse. Mean inclination for core site means is represented with a thick blue small circle, with $\alpha_{95}$ uncertainty depicted as bracketing thin blue small circles. The declination offsets in core samples, generally $\sim 10-60^{\circ}$ and reaching a maximum of $\sim 125^{\circ}$ in C-152, are likely related to vertical-axis orientation error during the coring process. 


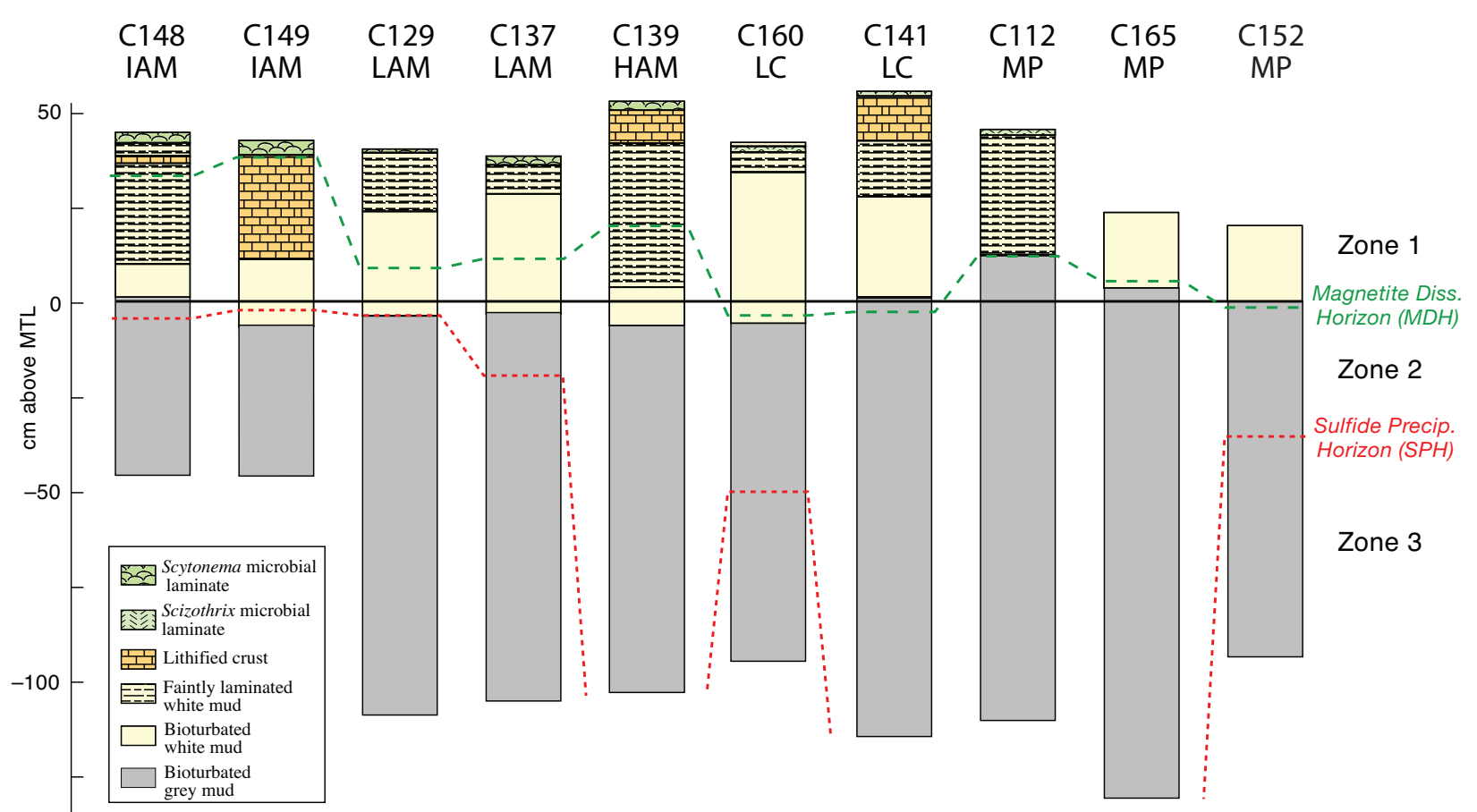

Figure 9. Redox zones of cores determined from changes in ferromagnetic material, as measured by total FMR absorption, IRM strength, and/or NRM intensity. The boundaries between zones are defined by the magnetite dissolution horizon (MDH) between zones 1 and 2, which corresponds to a drop-off in the concentrations of ferromagnetic material, and the sulfide precipitation horizon (SPH) between zones 2 and 3 , which corresponds to a return to higher concentrations of ferromagnetic material.

a lower zone of relatively high magnetization (Zone 3). In concert with the geochemical analyses, these data suggest that three major processes control the magnetic mineralogy of Triple Goose Creek sediments: (1) the deposition or precipitation of magnetite in the upper sediments, (2) the reductive dissolution of magnetite, and (3) in some areas, the reduction of marine sulfate and subsequent precipitation of magnetic iron sulfides. The depth of the transitions between the zones vary among the cores. The boundary between the zones are defined by two horizons, a magnetite dissolution horizon (MDH) between zones 1 and 2 and a sulfide precipitation horizon (SPH) between zones 2 and 3 (Figs. 9, 10).

Surface samples exhibit a broad range of FMR properties and strength of magnetization, likely reflecting the diversity of processes operating at the surface. These processes include the deposition of aeolian dust, both directly and after aqueous reworking, other aqueous transport processes, and biological processes including microbial metabolism and shallow burrowing.

The coercivities of the surface sediments, which range between 32 and $77 \mathrm{mT}$, are consistent with magnetite as the main magnetic carrier. We find no magnetic evidence for a significant contribution of high coercivity antiferromagnetic minerals such as hematite or goethite, nor can we find such minerals in TEM/EDS experiments. As hematite and goethite are the major iron oxides in North African dust (Balsam et al., 1995; Larrasoana et al., 2003), this suggests that iron minerals in aeolian dust are not significantly preserved even in the surface sediment. Aeolian-transported paramagnetic $\mathrm{Fe}$ (III)-bearing clay minerals may, however, contribute to the $\mathrm{Fe}(\mathrm{III})$ peak observed 
in the FMR spectra.

The heterogeneity displayed by the surface sediments is diminished greatly in the top $\sim \mathrm{cm}$ of the cores, which may reflect biological redox cycling of iron. Superparamagnetic magnetite or maghemite, the presence of which is indicated in the FMR spectra, may be produced in the upper zone of the sediment cores as a byproduct of microbial Fe(III) reduction or Fe(II) oxidation. The FMR spectra also suggest a major role for magnetotactic bacteria in this zone. In culture, magnetite-producing magnetotactic bacteria preferentially produce magnetite under oxygen partial pressures of $\sim 10$ mbar, corresponding to dissolved $\mathrm{O}_{2}$ concentrations of $\sim 10-15 \mu \mathrm{M}$ (Bazylinski and Frankel, 2004). The microelectrode data through Schizothrix and Scytonema mats suggest that oxygen-depleted microenvironments, hospitable to magnetotactic bacteria, occur in the mats. Such microenvironments are likely more abundant at night, when photosynthesis ceases, than during the day, when we performed our measurements (Jørgensen et al., 1979). A broader sub-zone of appropriate oxygen concentrations occurs in the sediment cores, and we suggest that the regions with clear double peaks in the coercivity spectra and often ARM/IRM maxima reflect the greatest abundance of magnetite produced by magnetotactic bacteria.

Just below the magnetotactic bacteria-enriched subzone is the MDH and the transition into Zone 2. At the MDH, oxygen and nitrate levels are sufficiently low that Fe(III) becomes the main electron acceptor for microbial respiration. Magnetite is reduced to $\mathrm{Fe}^{2+}$ in reactions such as

$\mathrm{C}_{6} \mathrm{H}_{12} \mathrm{O}_{6}+12 \mathrm{Fe}_{3} \mathrm{O}_{4}+66 \mathrm{H}^{+} \rightarrow 6 \mathrm{HCO}_{3}^{-}+36 \mathrm{Fe}^{2+}+36 \mathrm{H}_{2} \mathrm{O}$

as has been demonstrated in pure cultures of Shewanella (Kostka and Nealson, 1995; Dong et al., 2000). This reaction consumes protons and would promote carbonate cementation. This metabolic process is thermodynamically favorable at environmental $\mathrm{pH}$ levels so long as $\mathrm{Fe}^{2+}$ concentrations remain below $\sim 100 \mu \mathrm{M}$ (Kostka and Nealson, 1995), which suggests an important role for carbonate and/or sulfide precipitation in limiting the accumulation of ferrous iron. The mildly elevated particulate $\mathrm{Mn}$ (II) levels in this zone reflect the parallel reduction of oxidized $\mathrm{Mn}$ and the precipitation of $\mathrm{Mn}(\mathrm{II})$ in carbonate or sulfide minerals.

The MDH dissolution horizon is present in all the sediment cores (Fig. 9). It occurs near MTL in LC and MP environments and above MTL in algal marsh environments. The depth is controlled by the oxygen consumption rate, which is a function of biological productivity. In the algal marsh environment, the surface and near-surface sediments are rich in organic carbon, with the acid insoluble content reaching as high as $13 \%$ by weight. Differences in biological productivity in other settings may alter the thickness of the oxic zone.

In some cores, sulfate reduction leads to the presence of Zone 3. At and below the SPH, microbial sulfate reduction produces dissolved sulfide, which can then react with dissolved $\mathrm{Fe}^{2+}$ to produce first iron monosulfide minerals and then the ferrimagnetic mineral greigite in reactions such as:

$\mathrm{C}_{6} \mathrm{H}_{12} \mathrm{O}_{6}+3 \mathrm{SO}_{4}^{2-} \rightarrow 6 \mathrm{HCO}_{3}^{-}+3 \mathrm{HS}^{-}+3 \mathrm{H}^{+}$

$\mathrm{Fe}^{2+}+\mathrm{HS}^{-} \rightarrow \mathrm{FeS}+\mathrm{H}^{+}$ 
$3 \mathrm{FeS}+\mathrm{S}^{0} \rightarrow \mathrm{Fe}_{3} \mathrm{~S}_{4}$

By acidifying porewaters, this reaction also promotes dissolution of carbonate and might lead to the destruction of magnetic remanence carried in lithified carbonate crusts formed at or above the MDH. Particulate Mn(II) concentrations increase in parallel with the increase in total FMR absorption, which suggests the precipitation of $\mathrm{Mn}$ (II) as a cation in sulfide minerals or its adsorption onto iron sulfides (Arakaki and Morse, 1993).

In marine sediments, seawater sulfate is abundant. The development of sulfate reduction is controlled by the depletion of higher potential electron acceptors and by electron donor limitation. High potential electron acceptors like oxygen and nitrate are consumed in Zone 1, while medium potential electron acceptors like ferric iron are consumed in Zone 2. The presence of a sulfatereduction zone is therefore likely controlled by the availability of electron donors, primarily organic carbon, in sediments deep enough that high and medium potential donors have been reduced.

Zone 3 is not present in two MP cores, one LC core, and one HAM core. In two IAM and one LAM cores, it occurs near MTL, while in one LAM core, one LC core, and one MP core, it occurs $\sim 20-50 \mathrm{~cm}$ below MTL (Fig. 9). The sulfidic sediments in Zone 3 are richer in organic carbon than the sediments that overlie them. Visual inspection indicates that mangrove root hairs are richer in the acid insoluble component of $\mathrm{C} 149$, which has a Zone 3, than in the acid insoluble component of $\mathrm{C} 139$, which does not. This difference suggests that organic matter from decaying mangrove roots may exert an important control over the presence and depth of Zone 3.

The iron cycle model described above predicts that the remanent magnetization in Zone 1 is predominantly a chemical remanent magnetization produced near the time of deposition, while the remanent magnetization in Zone 3 is a chemical remanent magnetization produced significantly after deposition (Fig. 10). The absence of the depth trends in inclination expected from syndepositional remanent magnetizations supports this model. However, the accuracy of the paleomagnetic data is limited by the orientation system used in this study.

Our analyses of the Andros Island sediments have implications for the interpretation of paleomagnetic data from weakly magnetic carbonate platform sediments with limited to non-existent clastic input. Magnetic data from a single shoaling-upward meter-scale parasequence will not carry a record of magnetization synchronous with $\mathrm{cm}$-scale sediment accumulation; rather, the most strongly magnetic parts of the parasequence will all carry a magnetic record formed at the time of carbonate cementation/lithification. At Triple Goose Creek, cementation occurs syn-depositionally in the intertidal-to-supratidal top of the parasequence. Most compaction and cementation of the lower portion of the parasequence that was deposited subtidally and currently resides below the MTL occurs intracyclically, either after (1) a sea level drop leaves the entire parasequence above MTL, or (2) the parasequence is deeply buried. Therefore, it is the laminated, early-cemented top of the parasequence that is most likely to preserve a syn-depositional magnetic direction, and is also the region most likely to preserve a fossil record of magnetotactic bacteria.

If sedimentation in the Triple Goose Creek region were controlled by purely autocyclic processes, sediments would continue to aggrade until no accommodation space remained and a weathering horizon or hiatal surface developed. Early lithification would likely protect some of the magnetite 


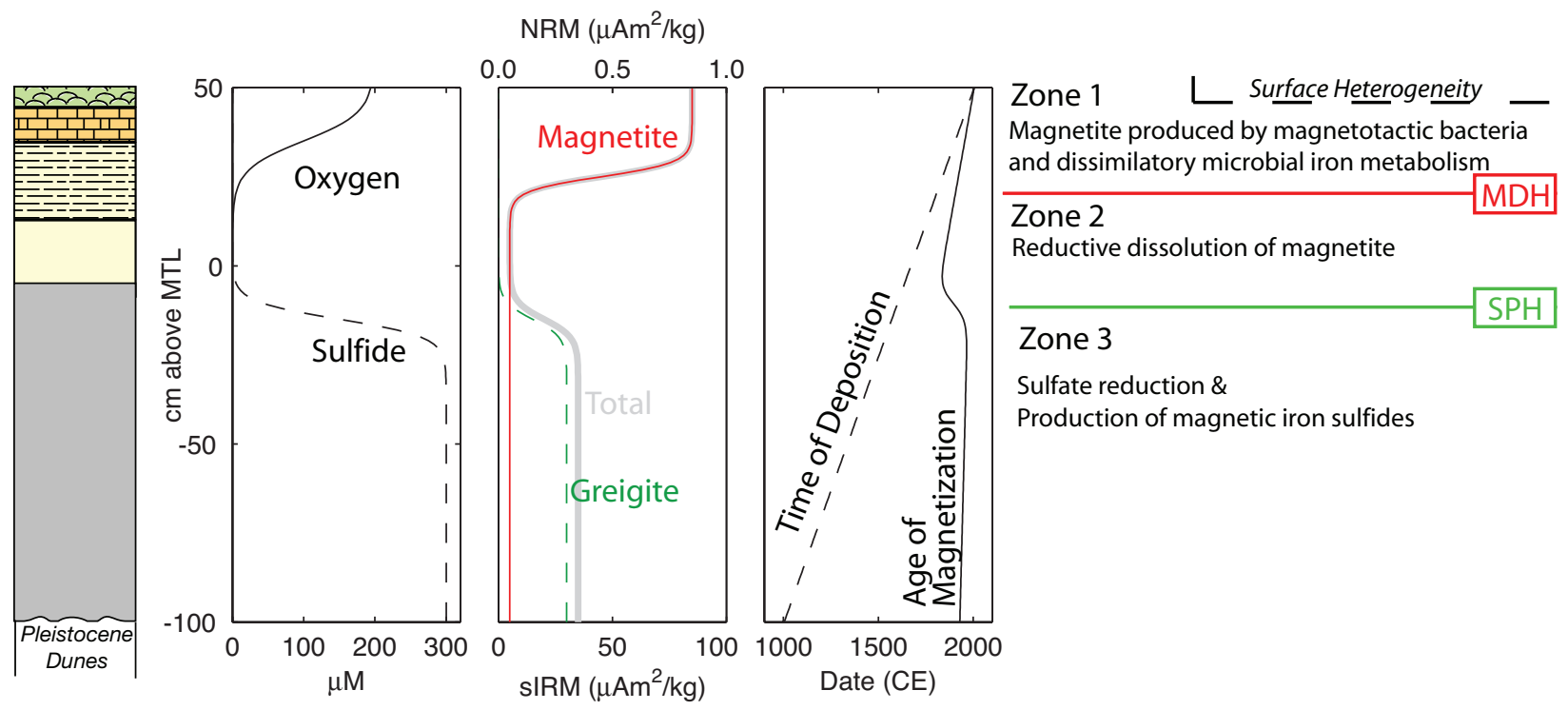

Figure 10. Schematic representation of the biogeochemical processes affecting the magnetic properties of Triple Goose Creek sediments.

in the upper laminated sediments and thereby preserve both a nearly syndepositional record of remanent magnetization and fossil magnetotactic bacteria. If sea level were to fall drastically in response to the onset of the next ice age, the Holocene parasequence would be left high and dry, and deep oxidative weathering might destroy the primary magnetic signal in the carbonates. In the more likely short-term scenario that anthropogenic climate warming leads to a rapid rise in eustatic sea level, the fast rise might overtake the rate of carbonate accumulation, flood the TGC area, and allow iron respiration to erase the magnetic record in all but the most impermeable, cemented portions of the upper part of the Holocene parasequence.

\section{Conclusions}

Our study of $\sim 1-2 \mathrm{~m}$ thick late Holocene peritidal carbonate sediments from the Triple Goose Creek region of Andros Island reveals an iron biogeochemical cycle divided, from a magnetic perspective, into three parts. We find evidence for a prominent role for magnetotactic bacteria in a zone constituting the upper $\sim 5-30 \mathrm{~cm}$ of the sediments. Below this zone, at a boundary that lies near or above mean tide level, iron reduction leads to a 5-10 fold drop in the magnetic strength of the sediments. Where decaying mangrove root fibers supplement the levels of organic carbon, a zone of sulfate reduction and a co-occurring increase in magnetization due to greigite precipitation can develop deeper in the subtidally deposited, bioturbated sediments.

Our results suggest that the lower portion of shoaling-upward peritidal carbonate parasequences are likely to be magnetically weaker than the tops of the parasequences and, where not weaker, likely record a slightly post-depositional magnetization contemporary with the magnetization of the top of the parasequence. The best target for recovering paleomagnetic signals with high temporal resolution from ancient peritidal carbonates, as well as the best target for finding ancient peritidal mag- 
netofossils, are therefore the early-cemented, laminated tops of shoaling-upward parasequences.

\section{Acknowledgements}

This project was supported by an Agouron Postdoctoral Fellowship to ACM, and Agouron Institute grants to JPG and JLK. REK was supported by a Moore Foundation fellowship and a grant from NASA ASTID. We appreciate keen field observations from John Abelson, Chris Guthrie, Peter Johnson, Jim Dahlberg, and Elsebet Lund and logistical support from Joan Kobori. We thank Angelo Di Bilio for support with the EPR spectrometer and David Mohrig and John Woodruff for stimulating discussions. Amy Myrbo and Anders Noren at the Limnology Research Center (University of Minnesota) provided us with coring equipment and a wealth of practical knowledge. This work would not have been possible without the genius of Roberta Bennett-Calorio, field assistance from Jay Ewing, able seamanship of Bradley Mackey, and logistical support from Agent Nixon of the Andros Island Police and Jeff Birch and the staff of Small Hope Bay Lodge.

\section{References}

Arakaki, T., Morse, J. W., 1993. Coprecipitation and adsorption of Mn(II) with mackinawite (FeS) under conditions similar to those found in anoxic sediments. Geochim. Cosmochim. Acta 57, 9-14.

Balsam, W. L., Ottobliesner, B. L., Deaton, B. C., 1995. Modern and Last Glacial Maximum eolian sedimentation patterns in the Atlantic Ocean interpreted from sediment iron-oxide content. Paleoceanography 10, 493-507.

Bazylinski, D. A., Frankel, R. B., 2004. Magnetosome formation in prokaryotes. Nature Rev. Microbiol. 2, 217-230.

Bazylinski, D. A., Garrattreed, A. J., Frankel, R. B., 1994. Electron-microscopic studies of magnetosomes in magnetotactic bacteria. Microscopy Research and Technique 27, 389-401.

Belkaaloul, N. K., Aissaoui, D. M., 1997. Nature and origin of magnetic minerals within the Middle Jurassic shallow-water carbonate rocks of the Paris Basin, France: implications for magnetostratigraphic dating. Geophys. J. Int. 130, 411-421.

Chang, S. B. R., Kirschvink, J. L., 1989. Magnetofossils, the magnetization of sediments, and the evolution of magnetite biomineralization. Annu. Rev. Earth Planet. Sci. 17, 169-195.

Chang, S. B. R., Stolz, J. F., Kirschvink, J. L., Awramik, S. M., 1989. Biogenic magnetite in stromatolites. 2. occurrence in ancient sedimentary environments. Precamb. Res. 43, 305-315.

Cisowski, S., 1981. Interacting vs. non-interacting single-domain behavior in natural and synthetic samples. Phys. Earth Planet. Int. 26, 56-62.

Cleveland, W. S., 1979. Robust locally weighted regression and smoothing scatterplots. J. Am. Stat. Assoc. 74, 829-836.

Courtillot, V., Gallet, Y., Le Mouel, J.-L., Fluteau, F., Genevey, A., 2007. Are there connections between the earth's magnetic field and climate? Earth Planet. Sci. Lett. 253, 328-339.

Crook, N. P., Hoon, S. R., Taylor, K. G., Perry, C. T., 2002. Electron spin resonance as a high 
sensitivity technique for environmental magnetism: determination of contamination in carbonate sediments. Geophys. J. Int. 149, 328-337.

Dong, H. L., Fredrickson, J. K., Kennedy, D. W., Zachara, J. M., Kukkadapu, R. K., Onstott, T. C., 2000. Mineral transformation associated with the microbial reduction of magnetite. Chem. Geol. 169, 299-318.

Evans, M. E., Heller, F., 2003. Environmental Magnetism: Principles and Applications of Enviromagnetics. Academic Press, San Diego.

Fuller, M., Kidane, T., Ali, J., 2002. AF demagnetization characteristics of NRM, compared with anhysteretic and saturation isothermal remanence: an aid in the interpretation of NRM. Phys. Chem. Earth 27, 1169-1177.

Hardie, L., 1977. Sedimentation on the Modern Carbonate Tidal Flats of Northwest Andros Island, Bahamas. No. 22. The Johns Hopkins University Press, Baltimore.

Jackson, M., 1990. Diagenetic sources of stable remanence in remagnetized Paleozoic cratonic carbonates: a rock magnetic study. J. Geophys. Res. 95, 2753-2761.

Jackson, M., Sun, W.-W., Craddock, J., 1992. The rock magnetic fingerprint of chemical remagnetization in midcontinental Paleozoic carbonates. Geophys. Res. Lett. 19, 781-784.

Jones, C. H., 2002. User-driven integrated software lives: "PaleoMag" paleomagnetics analysis on the Macintosh. Computers and Geosciences 28, 1145-1151.

Jørgensen, B. B., Revsbech, N. P., Blackburn, T. H., Cohen, Y., 1979. Diurnal cycle of oxygen and sulfide microgradients and microbial photosynthesis in a cyanobacterial mat sediment. Appl. Env. Microbiol. 38, 46-58.

Kirschvink, J. L., 1980. The least-squares line and plane and the analysis of paleomagnetic data. Geophys. J. Roy. Astr. Soc. 62, 699-718.

Kirschvink, J. L., Chang, S. B. R., 1984. Ultrafine-grained magnetite in deep-sea sediments - possible bacterial magnetofossils. Geology 12, 559-562.

Kopp, R. E., Nash, C. Z., Kobayashi, A., Weiss, B. P., Bazylinski, D. A., Kirschvink, J. L., 2006a. Ferromagnetic resonance spectroscopy for assessment of magnetic anisotropy and magnetostatic interactions: A case study of mutant magnetotactic bacteria. J. Geophys. Res. 111, B12S25, doi:10.1029/2006JB004529.

Kopp, R. E., Weiss, B. P., Maloof, A. C., Vali, H., Nash, C. Z., Kirschvink, J. L., 2006b. Chains, clumps, and strings: Magnetofossil taphonomy with ferromagnetic resonance spectroscopy. Earth Planet. Sci. Lett., 10-25.

Kostka, J. E., Nealson, K. H., 1995. Dissolution and reduction of magnetite by bacteria. Env. Sci. Tech. 29, 2535-2540.

Larrasoana, J. C., Roberts, A. P., Rohling, E. J., Winklhofer, M., Wehausen, R., 2003. Three million years of monsoon variability over the northern Sahara. Climate Dyn. 21, 689-698.

Li, Y.-L., Vali, H., Sears, S., Yang, J., Deng, B., Zhang, C., 2004. Iron reduction and alteration of nontronite NAU-2 by sulfate-reducing bacterium. Geochim. Cosmochim. Acta 68, 3251-3260.

Maloof, A., Grotzinger, J., in prep. The origin of meter-scale parasequences in platformal carbonates - Holocene stratigraphy Triple Goose Creek, Andros Island, Bahamas. Geol. Soc. Am. Bull.

Maloof, A. C., Halverson, G. P., Kirschvink, J. L., Schrag, D. P., Weiss, B. P., Hoffman, P. F., 2006. Combined paleomagnetic, isotopic, and stratigraphic evidence for true polar wander from the Neoproterozoic Akademikerbreen Group, Svalbard, Norway. Geol. Soc. Am. Bull. 118, 1099_ 1124. 
McCabe, C., Elmore, R., 1989. The occurrence and origin of Late Paleozoic remagnetization in the sedimentary rocks of North America. Rev. Geophysics 27, 471-494.

McCabe, C., Jackson, M., Saffer, B., 1989. Regional patterns of magnetite authigenesis in the Appalachian Basin: Implications for the mechanism of Late Paleozoic remagnetization. J. Geophys. Res. 94, 10,429-10,443.

McCabe, C., Van der Voo, R., Peacor, D., Scotese, C., Freeman, R., 1983. Diagenetic magnetite carries ancient yet secondary remanence in some Paleozoic sedimentary carbonates. Geology 11, 221-223.

McNeill, D. F., 1990. Biogenic magnetite from surface holocene carbonate sediments, great bahama bank. J. Geophys. Res. 95, 4363-4371.

McNeill, D. F., 1997. Facies and early diagenetic influence on the depositional magnetization of carbonates. Geology 25, 799-802.

McNeill, D. F., Ginsburg, R. N., Chang, S. B. R., Kirschvink, J. L., 1988. Magnetostratigraphic dating of shallow-water carbonates from San Salvador, Bahamas. Geology 16, 8-12.

McNeill, D. F., Kirschvink, J. L., 1993. Early dolomitization of platform carbonates and the preservation of magnetic polarity. J. Geophys. Res. 98, 7977-7986.

Montgomery, P., Hailwood, E. A., Gale, A. S., Burnett, J. A., 1998. The magnetostratigraphy of Coniacian-late Campanian chalk sequences in southern England. Earth Planet. Sci. Lett. 156, 209-224.

Moore, J., Doney, S., Glover, D., Fung, I., 2002. Iron cycling and nutrient-limitation patterns in surface waters of the World Ocean. Deep-Sea Res. 49, 463-507.

Ohno, M., Hamano, Y., 1992. Geomagnetic poles over the past 10,000 years. Geophys. Res. Lett. 19, 1715-1718.

Petersen, N., von Dobeneck, T., Vali, H., 1986. Fossil bacterial magnetite in deep-sea sediments from the South Atlantic Ocean. Nature 320, 611-615.

Sakaguchi, T., Arakaki, A., Matsunaga, T., 2002. Desulfovibrio magneticus sp nov., a novel sulfatereducing bacterium that produces intracellular single-domain-sized magnetite particles. Int. J. Sys. Evol. Microbiol. 52, 215-221.

Sakai, S., Jige, M., 2006. Characterization of magnetic particles and magnetostratigraphic dating of shallow-water carbonates in the Ryukyu Islands, northwestern Pacific. Island Arc 15, 468-475.

Shinn, E., Ginsburg, R., Lloyd, R., 1969. Anatomy of a modern carbonate tidal-flat, Andros Island, Bahamas. J. Sed. Petr. 39, 1202-1228.

Simmons, S. L., Sievert, S. M., Frankel, R. B., Bazylinski, D. A., Edwards, K. J., 2004. Spatiotemporal distribution of marine magnetotactic bacteria in a seasonally stratified coastal salt pond. Appl. Env. Microbiol. 70, 6230-6239.

Stanjek, H., Fassbinder, J., Vali, H., Waegle, H., Graf, W., 1994. Evidence of biogenic greigite (ferrimagnetic $\mathrm{Fe}_{3} \mathrm{~S}_{4}$ ) in soil. Eur. J. Soil Sci. 45, 97-103.

Vali, H., Weiss, B., Li, Y.-L., Sears, S., Kim, S., Kirschvink, J., Zhang, C., 2004. Formation of tabular single-domain magnetite induced by Geobacter metallireducens GS-15. Proc. Nat. Acad. Sci. 101, 16121-161216.

Van der Voo, R., 1989. Paleomagnetism of continental North America: The craton, its margins, and the Appalachian belt. In: Pakiser, L., Mooney, W. (Eds.), Geophysical Framework of the Continental United States. Vol. 172. Geological Society of America Memoir, pp. 447-470.

Weiss, B. P., Kim, S. S., Kirschvink, J. L., Kopp, R. E., Sankaran, M., Kobayashi, A., Komeili, A., 2004. Ferromagnetic resonance and low temperature magnetic tests for biogenic magnetite. 
Earth Planet. Sci. Lett. 224, 73-89. 


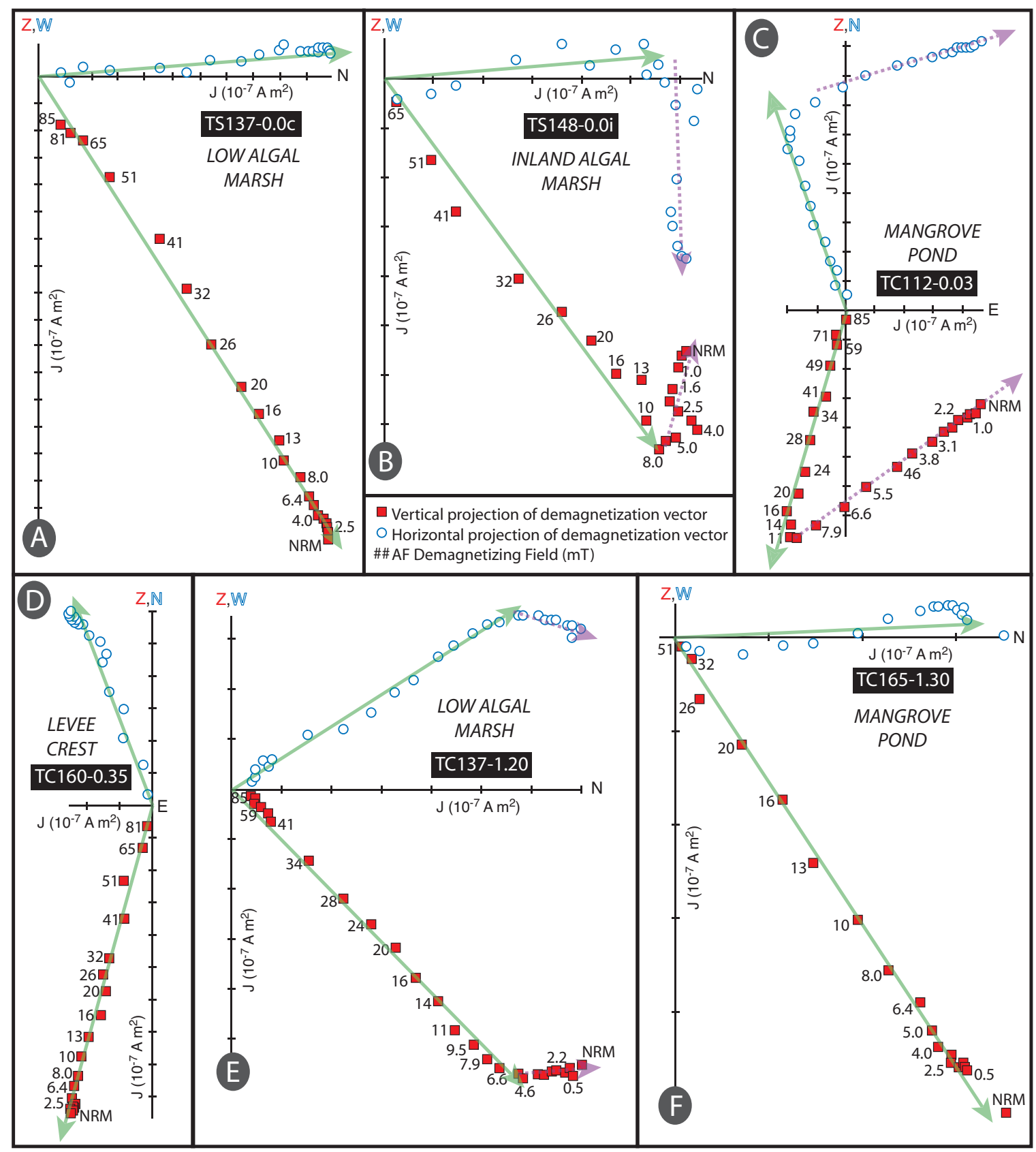

Figure S-1. Representative vector component diagrams showing AF-demagnetization behavior of TGC carbonate samples. A, E and F show single component behavior, where the high-AF magnetic component decays linearly to the origin (green arrow) during progressive AF-demagnetization from 0 to $85 \mathrm{mT}$. B,C and $\mathrm{E}$ show two-component behavior, where a low-AF overprint direction (purple arrow) is removed between 5 and $10 \mathrm{mT}$, before the high-AF component (green arrow) decays linearly to the origin. 